\title{
3次元地中構造物と地盤の弹塑性動的相互作用 に関する実験的研究
}

\section{大嶋義隆* 渡辺啓行**}

砂地盤模型およびその中に 3 次元地中構造物模型を設置した連成模型の振動実験を 行った。 その結果, 地盤のダイレタンシー特性によって水平方向加振が上下方向振動を 励起すること,この現象は塑性論を用いた時刻歴応答解析によりシミュレーションでき ることを示した．さらに，地中構造物には全側面にこの上下動による動土圧が作用する こと, 上下振動は構造物と地盤の動的相互作用の影響を強く受けることが明らかになっ た.

Key Words : 3-dimensional system, soil-structure interaction, model vibration tests, elasto-plastic dynamic analysis, dynamic earth pressure

\section{1.はじめに}

地中構造物や埋め込みを有する建築構造物の地震時挙 動は，地盤との動的相互作用を考慮して 2 次元有限要素 法を用いて解析することが多い，構造物がダクトやトン ネルであれば横断面をモデル化するのに 2 次元要素を用 いることに異論はないが，ピット状の地中構造物や建築 構造物の地震時挙動は 2 次元問題として対処するには無 理があり，3 次元の問題として取り扱うのが妥当であろ う. 例えば， 2 次元では紙面に平行（振動方向に平行） となる外壁面と地盤との動的相互作用，この面に作用す る地震時の土圧なよ゙は解析に考慮できないが, 構造物の 地震時挙動に大きな影響を与えることは確加と思われ る.さらに，地盤の持つ材料非線形性が動的相互作用を 一層複雑なものにする.

地盤は比較的ひずみが小さいうちから材料非線形性を 示し, 動的解析においてもこれを考慮した解析が必要で ある. 通常の構造物の耐震設計では最も影響の大きい地 震波として S 波 (世ん断波) を対象としているので, せん断応力之せん断ひずみの関係が重視されてきた.こ の関係をせん断ひずみの関数としてのせん断弾性係数之 減衰定数で表し, 動的線形計算に用いるのが等価線形化 法であり, 今日, 2 次元 FEM による非線形動的解析に 広く利用されていることは周知の通りである.しかし， これらの解析方法では地盤の持つ重要な非線形特性であ るダイレタンシー特性を考慮していない. 従来, ダイレ タンシー特性は間隙水圧との関係で液状化の研究で取り 扱われ，地盤振動の分野で研究されることはなかった. しかし, 土のような粒状体はせん断応力によって体積変 化が生じ, その変化量は圧縮力によって生ずるよりも遥

* 正会員 前田建設工業（株）土木設計本部

( 179 東京都練馬区高松 5 丁目 8 番 J. CITY)

**正会員 工博 埼玉大学教授 工学部建設工学科
かに大きい場合が有り得る1のだから，この特性は地盤 振動に大きな影響を与えると思われる.

3 次元の構造物之地盤の動的相互作用に関する既往の 研究亡して, 三浦の研究 ${ }^{21}$, 土岐らの研究 ${ }^{31}$, 石原らの 研究中が挙げられる. 文献 2) は基盤上の地中基礎構造物 と表層地盤の動的相互作用を 3 次元波動論に基づき解析 した研究であるが，地盤を粘弾性体と仮定しているので 地盤のひずみが大きくなる強震時は適用外である. 文献 3), 文献 4) は地上構造物と地盤の 3 次元 FEMによる 動的解析である. 前者は構造物と地盤の接触面にジョイ ント要素を配し剝離と滑動現象に注目した研究で，地盤 は線形弾性体と仮定している，後者は地盤を弾性完全塑 性体と仮定し, Mohr-Coulomb の破壊規準を 3 次元応 力空間で用いているが，ダイレタンシー特性を考慮して いない.さらに，これらの研究は実験結果または観測結 果に基づくものではない.

そこで本研究では, まず, 強震時の地盤振動特性を把 握する目的で砂地盤模型による振動実験を行った. 次に, 地盤を Cap を持つ Drucker-Prager 材料としてモデル化 し, 塑性流れを考慮した弾塑性論に基づく時刻歴応答解 析を行った.さらに，この地盤中に 3 次元地中構造物模 型を設置し振動実験を行った. その結果, ダイレタンシー 特性によって水平方向加振が上下動を励起すること, そ のために振動方向と平行な外壁面には上下動による動土 圧が，垂直な外壁面には上下動と水平動による動土圧が 作用することが明らかになった。

\section{2. 模型振動実験}

\section{（1）模型振動実験}

本実験では原子力発電所海水ポンプ室のように構造物 天端が地表面と一致するような箱型埋設地中構造物を対 象とした. 地盤は岩盤上に厚さ $50 \mathrm{~m}$, 平均的なせん断 波速度 $200 \mathrm{~m} / \mathrm{sec}$ の砂層地盤を想定した.この地盤の物 
Table 1 Law of Similitude in Models of Pit and Ground

\begin{tabular}{|c|c|c|c|c|c|}
\hline \multirow{2}{*}{\multicolumn{2}{|c|}{ Quantity }} & \multirow{2}{*}{$\begin{array}{c}\text { Law of } \\
\text { Similitude }\end{array}$} & \multicolumn{3}{|c|}{ Value of Every quantity } \\
\hline & & & Prototype & Target value & Attained Value \\
\hline \multirow{3}{*}{$\mathrm{RC}$} & \begin{tabular}{|l} 
Length (mn) \\
Height \\
Width \\
Thickness
\end{tabular} & $\begin{array}{l}1 / \lambda \\
(1 / 100)\end{array}$ & $\begin{array}{l}30000 \\
15000 \\
21000 \\
1500\end{array}$ & $\begin{array}{r}300 \\
150 \\
210 \\
15\end{array}$ & $\begin{array}{r}300 \\
150 \\
210 \\
15\end{array}$ \\
\hline & $\begin{array}{c}\text { Density } \\
\left(\mathrm{g} / \mathrm{cm} \mathbf{m}^{3}\right)\end{array}$ & $\begin{array}{l}1 / n \\
(1 / 1.315)\end{array}$ & 2.4 & 1.825 & 1.19 \\
\hline & \begin{tabular}{|l|} 
Young's \\
Mbdulus \\
(kgf/ann $\left.{ }^{2}\right)$
\end{tabular} & $1 /(\lambda \eta)^{1 / 2}$ & $24 \times 10^{5}$ & $2.09 \times 10^{4}$ & $\begin{array}{r}2.4 \times 10^{4} \sim \\
3.0 \times 10^{4}\end{array}$ \\
\hline \multirow{3}{*}{ Soil } & \begin{tabular}{|l|} 
Depth of \\
Layer (mn)
\end{tabular} & \begin{tabular}{|l|}
$1 / \lambda$ \\
$(1 / 100)$
\end{tabular} & 50000 & 500 & 500 \\
\hline & $\begin{array}{l}\text { Density } \\
\left(\mathrm{gf} / \mathrm{cm}^{3}\right)\end{array}$ & $\begin{array}{l}1 / n \\
(1 / 1.315)\end{array}$ & 1.8 & 1. 369 & 1. 369 \\
\hline & Vs $(\pi / \mathrm{sec})$ & $(n / \lambda)^{1 / 4}$ & 200 & 68 & $58 \sim 76 \times 11$ \\
\hline
\end{tabular}

*1) ; Calculated value from resonance curves of response accelerations $1 \mathrm{gf} / \mathrm{cm}^{3}\left(9.8 \mathrm{kN} / \mathrm{m}^{3}\right) \quad 1 \mathrm{kgf} / \mathrm{cm}^{2} \quad\left(98 \mathrm{kN} / \mathrm{m}^{2}\right)$

性は比較的軟質な砂地盤に相当するものである.

地中構造物一地盤連成系模型の振動挙動は力の比を一 定とする相似則に従うと考え, 構造物の諸元は香川・国 生の相似則 ${ }^{51,6)}$ に基づき Table 1 のように決定した。こ の相似則は支配方程式に基づく井合の相似則 ${ }^{7} に$ 包含さ れるもので, 地盤模型の振動実験のように非線形物性が 問題となり，また重力の加速度を変えることができない 実験に適している. 構造物模型の材料はこの相似則によ るヤング率を比較的満足するものとしてアクリル板を用 いた. また, 構造物の剛性の影響を検討するために板厚 を1/3とした模型も製作した。模型の表面には粗度を増 すために地盤材料と同じ砂を全表面に一様に塗布した. 構造物模型の諸元を Fig.1 に示す.

模型地盤材料には気乾状態の岐阜砂を用いた。これを 振動台上のせん断土槽内に構造物模型あるいは加速度計 の設置深さまで気中落下により詰め, $300 \mathrm{gal}, 25 \mathrm{~Hz}$ の 振動を加えて沈下分の砂を補充しながら締固め, 沈下が 進行しないことを確認した後構造物模型と加速度計を設 置した.この操作を地表面まで繰り返した後さらに再度 振動締固めを行った。このようにして作成した地盤の動 的物性は次式のように示される

$$
\begin{aligned}
\frac{G}{G_{0}} & =\frac{2.95 \times 10^{-4}}{2.95 \times 10^{-4}+\gamma} \cdots \ldots \ldots \ldots . . . . . \\
h & =0.337 \frac{\gamma}{\gamma+2.95 \times 10^{-4}} \cdots \cdots \ldots . . \\
G_{0} & =700 \frac{(2.17-e)^{2}}{1+e}\left(\sigma_{m}^{\prime}\right)^{0.321} \ldots . .
\end{aligned}
$$

ここに, $G$ はせん断弾性係数, $G_{0}$ は初期せん断弾性係数, $h$ は減衰定数, $\gamma$ はせん断ひずみ, $e$ は間隙比, $\sigma_{m}^{\prime}$ は拘 束圧である。

実験に使用したせん断土槽は 16 枚の軽量形鋼矩形枠 をボールベアリングを介して重ね，その内壁と外壁にゴ ム膜を貼ったもので，内法寸法は長さ $1.2 \mathrm{~m}$, 幅 $0.8 \mathrm{~m}$, 深さ $0.96 \mathrm{~m}$ である. 土槽単体の固有振動数は $1.6 \mathrm{~Hz}$ で ある。
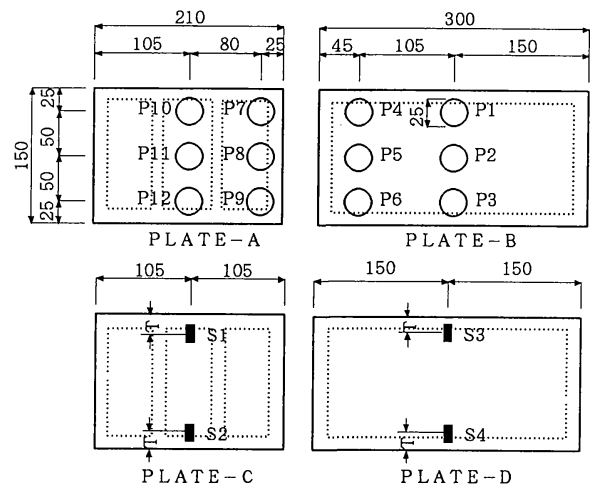

$T=t+5$

$\mathrm{t}$; Tickness of Plate

$\bigcirc$ Earth Press. Meter

- Acc. Meter

- Strain Gauge
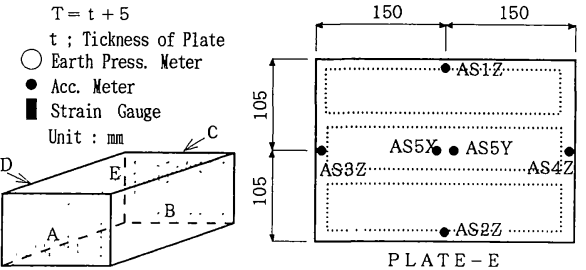

Fig.1 Dimension of Model Pit and Arrangement of Sensors
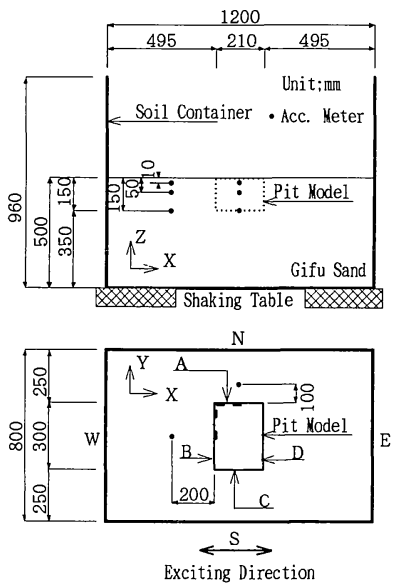

Fig.2 Soil Structure Model and Arrangement of Sensors

\section{（2）実験ケースと計測方法}

地盤と地中構造物の基本的な振動特性の把握を目的と して振動実験は水平方向正弦波による共振実験とした. 実験は自由地盤の 1 ケースと構造物模型の板厚を変えた 2 ケースの計 3 ケースとし，それぞれのケースで加速度 を一定にして振動数を $10 \mathrm{~Hz}$ から $60 \mathrm{~Hz}$ の範囲で変化さ せた.この際, 地盤の 1 次固有振動数付近は $1 \mathrm{~Hz}$ 刻み で測定した．実験は入力加速度 50，100，200 gal の順 で行い, 入力加速度を変える時は振動台を一旦停止した. この時連成系の実験ではひずみゲージの零調整を行い, 静止状態の土圧を測定した.

自由地盤の振動実験ではせん断土槽に $50 \mathrm{~cm}$ の砂を 入れ, せん断土槽中央部に地表面加ら $1 \mathrm{~cm}, 3 \mathrm{~cm}, 5 \mathrm{~cm}$, $15 \mathrm{~cm}$ の深さの位置に加速度計を設置した.

構造物一地盤連成系では地盤と構造物の加速度, 構造 


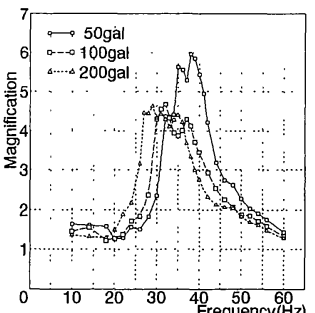

(a) Horizontal(GL-1cm)

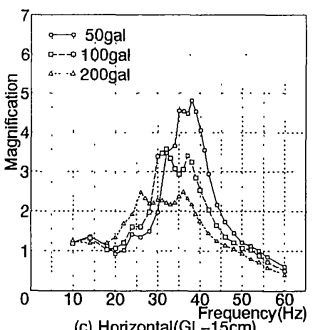

(c) Horizontal(GL-15cm)

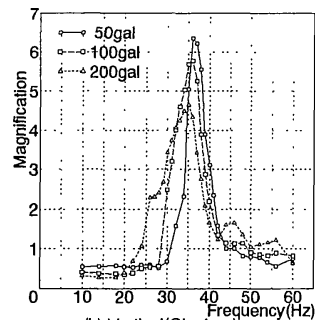

(b) Vertical(GL-1cm)

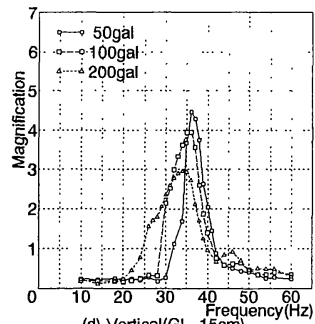

(d) Vertical(GL-15cm)
Fig.3 Resonance Curves of Measured Response Accelerations of Free Ground Model

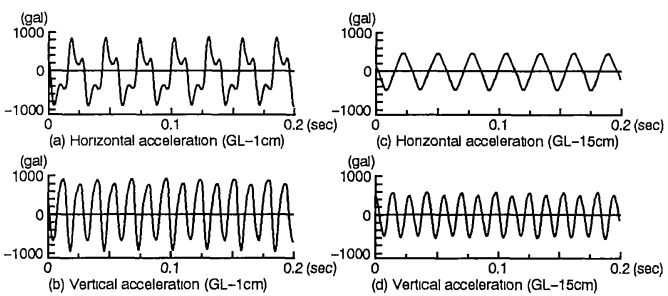

Fig.4 Measured Response Accelerations of Free Ground Model (200 gal, $35 \mathrm{~Hz}$ )

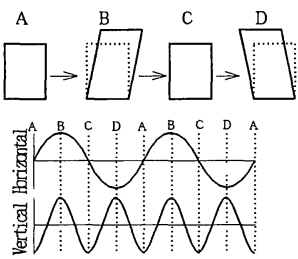

Fig.5 Schematic of Vertical Vibration produced by Dilatancy
物に作用する土圧および構造物の曲げひずみを測定し た. 土圧計は土圧による圧力上昇を拡散型半導体素子で 検出するもので, 最大測定容量は $500 \mathrm{gf} / \mathrm{cm}^{2}$ である. この土圧計は受圧面が構造物模型の側壁表面と同一平面 をなすよう内側からセットした. Fig.2 に計測機器の配 置図を示す.測定データはフロッピーディスクに記録し， デー夕処理時には記録波形の中から定常状態の連続した 10 波形を選び出しその平均值を用いた。

\section{3. 実験 結果}

\section{（1）自由地盤の振動特性}

a) 自由地盤の応答加速度

Fig.3 は加速度共振曲線である.この図の横軸は入力 加速度の振動数を示し, 上下方向応答加速度の振動数は この振動数と同じではない.

水平方向応答加速度は入力加速度怔大きくなると応答 倍率が低下するとともに共振振動数が低振動数側にシフ トしている.これは, 本実験では地盤材料の非線形特性 か灝著に現れていることを示している.

上下方向応答加速度については, 水平方向加速度と同 様に入力加速度が大きくなると応答倍率は小さくなるが 共振曲線は明確なピークを持つ. ピーク值の上下応答振 幅を水平入力振幅で除した応答倍率は水平方向の值と同 等またはそれ以上の值を示している，また，入力加速度 の増加とともに共振曲線は低振動数側にシフトするが, 共振点がシフトすることに加え, 上下動発生の振動数が

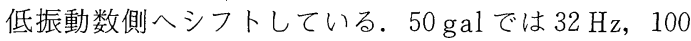
gal では $30 \mathrm{~Hz}, 200 \mathrm{gal}$ では $22 \mathrm{~Hz}$ より低い振動数では 上下方向加速度は生じない. Fig.3 の低振動数領域の若 干の応答倍率は加速度計測時の電気ノイズによる波形を
パソコンで機械的にデータ処理したためのものである.

Fig.4 は $200 \mathrm{gal}, 35 \mathrm{~Hz}$ の正弦波による加振実験時の 定常状態の応答波形である. 水平方向応答加速度は 35 $\mathrm{Hz}$ で振動しているが, 上下方向応答加速度はその 2 倍 の $70 \mathrm{~Hz}$ の振動数を持つ.このように, 上下方向応答加 速度は水平方向応答加速度の 2 倍の振動数を示すことが その特徵である。

b）上下方向加速度の生ずるメカニズム

この現象は, 地盤のダイレタンシーが原因であると考 えると説明できる.すなわち，せん断ひずみが小さいう ちはせん断変形のみ起こるので水平方向振動のみが生ず るが，大きくなると体積変化を伴うせん断変形之なり， それが上下振動を引き起こすのである. Fig.5 は密な砂 の変形状態を示したものであるが, $\mathrm{A}-\mathrm{B}-\mathrm{C}-\mathrm{D}-\mathrm{A}$ が水 平振動の 1 周期に相当する. 体積は $\mathrm{A}$ あるいは $\mathrm{C}$ で最 小，Bあるいは D で最大となるから $\mathrm{A}-\mathrm{B}-\mathrm{C}$ あるいは C-D-A が上下振動の 1 周期之なる。したがって, 上下 振動の振動数は水平振動の 2 倍亡なる.

c) FEM に上る弾塑性時刻歴応答解析

塑性流れの理論では塑性ひずみ増分は塑性ポテンシャ ル関数の外向き法線ベクトルの方向に生ずるとするが, 本研究では塑性ポテンシャル関数が降伏規準に一致する と仮定する関連流れ則を用いた。ダイレタンシーは塑性 ひずみ増分の体積変化を示す成分で表される. 土の材料 試験では Mohr-Coulomb の降伏規準が実験結果によく 合うことが知られているが，この降伏曲面は 3 次元主応 力空間で歪んだ六角錐をなし，隅角部が数值計算上の特 異点となる. Drucker-Prager の降伏曲面は 3 次元主応 力空間で静水圧軸を軸とする円錐をなし， M-C 降伏曲 面の第一近似とされている. 本解析では降伏規準として 


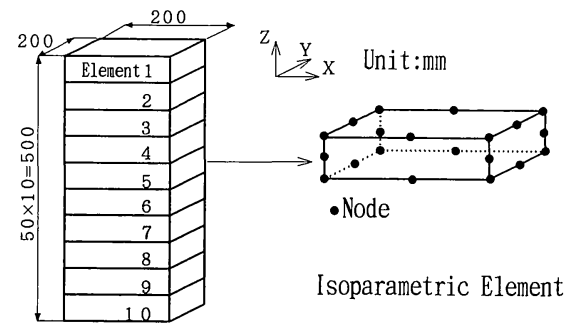

Fig.6 Finite Element Idealization of Free Ground in Numerical Model
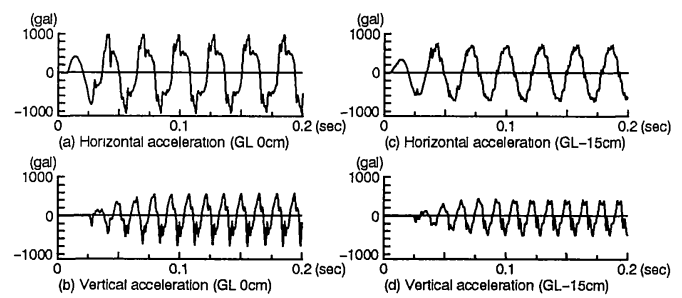

Fig.7 Predicted Response Accelerations of Free Ground (200 gal, $35 \mathrm{~Hz}$ )

Cap を持つ D-P 規準を用いた。 D-P の降伏規準 $f$ は次 のように表される゚!.

$$
f=\sqrt{J_{2}}-\alpha I_{1}-k \text {. }
$$

ここに, $\sqrt{J_{2}}$ は偏差応力テンソルの 2 次不変量, $I_{1}$ は応 カテンソルの 1 次不変量, $\alpha, k$ は材料定数で $\mathrm{M}-\mathrm{C}$ の 定数 $c, \varphi$ と関連づけられる．ここでは圧縮子午線上で $\mathrm{M}-\mathrm{C}$ の曲面に外接するよう $\alpha, k$ を次のように決めた.

$$
\begin{aligned}
& \alpha=\frac{2 \sin \varphi}{(3-\sin \varphi) \sqrt{3}} \\
& k=\frac{6 c \cos \varphi}{(3-\sin \varphi) \sqrt{3}}
\end{aligned}
$$

ここに $c$ は粘着力で $10 \mathrm{gf} / \mathrm{cm}^{2}, \varphi$ は内部摩擦角で 27.5 度とした ${ }^{81}$. せん断弾性係数は式（3）の $G_{0}$ を $35 \mathrm{~Hz}$ で共振するよう調整した物性値を与えた。地盤はアイソ パラメトッリック 6 面体の 20 節点要素101でモデル化し 要素分割はFig.6 のようにした。一般に FEMによる自 由地盤解析では要素の側面の境界条件は水平ローラー支 持とするが，これでは水平動と上下動が同時に起きる現 象のシミュレーションは不可能である．また，側面の境 界条件を X, Y,$Z$ 方向ともフリーにすると土柱の曲げ 振動が生じ，自由地盤の振動とは考えられない。これら を避けるために, XY 平面に平行な面は振動中も常に平 行を保持するようにZ座標が同じ節点を同一変位の条 件で拘束した．下端は固定境界とし，X 方向に $200 \mathrm{gal}$ ， $35 \mathrm{~Hz}$ の正弦波を入力した。

応答計算には直接積分法を用い，数値積分は New$\operatorname{mark} の \beta$ 法で $\beta=1 / 4$ ，時間刻みは $0.0005 \mathrm{sec}$ とした. 降伏曲面に達した場合には全節点の新しい変位と前回の

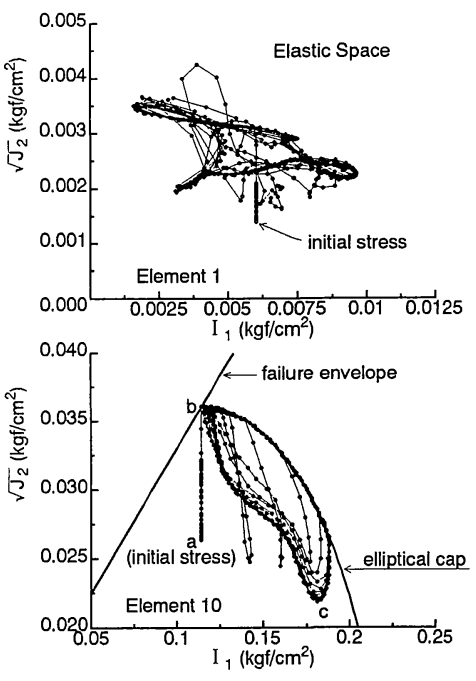

Fig.8 Predicted Stress Paths in Meridian Planes

变位の差が $1 \times 10^{-6} \mathrm{~cm}$ 以下になるまで初期応力法によ る反復計算を繰り返した。この方法による弾塑性解析の 収束は速く，演算時間は同じ条件の弾性解析の 2.3 倍に 過ぎず，等価線形解析に比べても演算時間は短い.

Fig.7 は GL-15 cm と地表面の応答加速度を示したも ので, 上下振動が水平振動の 2 倍の振動数を持つこと, 水平方向加速度波形の形状の特徵なゼ実験結果をよく再 現している. Fig. 8 は要素 1 と要素 10 の要素中心の応 力経路を三次元主応力空間内の子午面上で表したもので ある. 要素 10 の $\mathrm{a}$ は初期応力状態を示し, 最初は $a-b$ 間で振動する。この時, 応力経路は $\sqrt{J_{2}}$ 軸に平行にな り上下動は生じない，降伏曲面に達すると塑性体積ひず みによる上下動が生じ始め, $\mathrm{b}-\mathrm{c}$ のループで定常状態に なる. b はせん断応力の絶対值が最大, 圧縮応力最小の 応力点で, $\mathrm{c}$ はせん断応力が零, 圧縮応力最大に近い応 力点である. したがって，上下方向の 1 周期は $c-b-c$ となり，水平方向の 1 周期は ( $^{-}-b^{-}-c^{-b}-\mathrm{c}$ となる. この時, 2 度目のbのせん断応力の符号は 1 度目と逆転すること に注意すれば，これはFig.5の A-B-C-D-A に対応し ていることは容易にわかる. 要素 1 の応力は弾性域内で ねじれたループを描いているが，これは下方の要素の塑 性体積ひずみにより発生した上下動の影響を受けたため である。したがって, 地表面の水平方向加速度の波形が 正弦波でないのは地表面付近の土の応力状態が降伏曲面 に達したからではなく, 深部で発生した上下動の影響に よるものであることがわかる.

\section{（2）地盤一構造物連成系模型の振動特性}

以下の議論は板厚 $t=1.5 \mathrm{~cm}$ 模型の実験結果を中心に 進めるが，特に断りがない場合には $t=0.5 \mathrm{~cm}$ 模型でも 同様の現象である.

a) 構造物模型の振動特性 

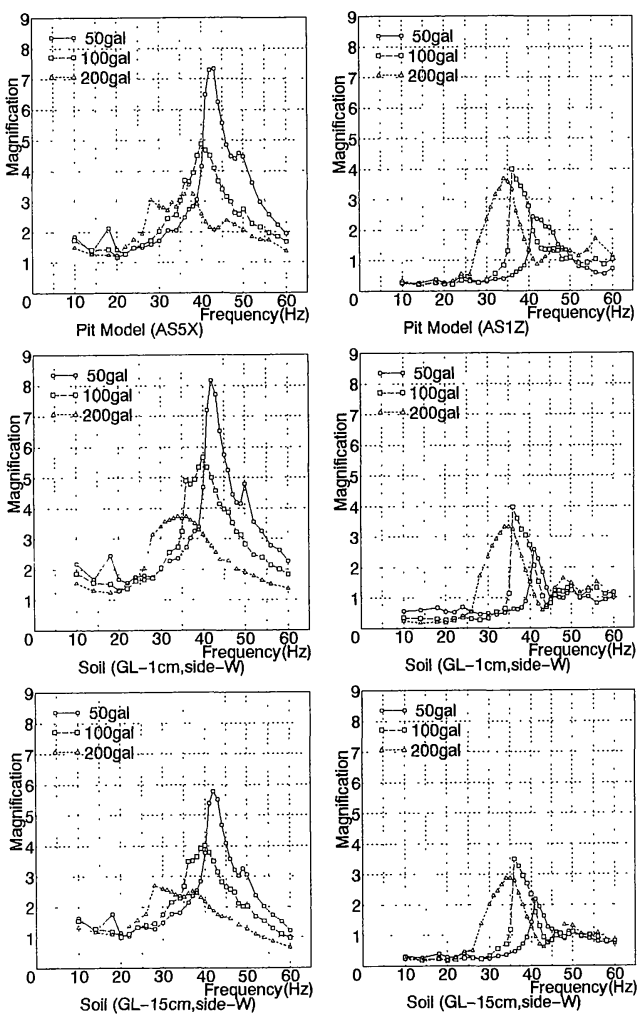

(a) Horizontal

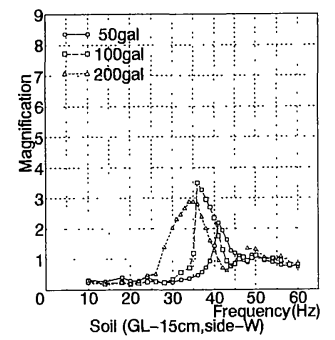

(b) Vertical

Fig.9 Resonance Curves of Response Accelerations of Soil-Structure Model

Fig.9 は板厚 $1.5 \mathrm{~cm}$ 模型の場合の Fig.1, Fig.2 に示 す測点の加速度共振曲線である. 模型天端の共振曲線は 地盤のものと水平，上下ともに形状がよく似ている.こ れは模型の応答が地盤の振動に支配されているためと考 えられる.なお, 共振状態では構造物模型天端に設置し た加速度計 AS1Z と AS2Zによる上下方向加速度の波 形に位相差はみられない。つまり，ロッキング振動より 上下振動の方がはるかに優勢である.

b）連成系地盤の振動特性

Table 2 は最大応答倍率と共振振動数に関して自由地 盤と連成系の地盤の場合を比較したものである．水平方 向応答加速度は自由地盤と比べると共振振動数は高い方 へ移行し応答倍率は増大している. これは構造物の存在 によって地盤のせん断ひずみが小さくなり, 等価線形解 析法で表現するところの剛性低下が少なく減衰も小さく なったためと考えられる．この傾向は入力加速度が小さ いほど顕著である.

上下方向応答加速度の共振振動数は $50 \mathrm{gal}, 100 \mathrm{~g} \mathrm{al}$ 入力時には自由地盤の場合より高い方へ移行するが, 最 大応答倍率は $100 \mathrm{gal}, 200 \mathrm{gal}, 50 \mathrm{gal}$ 入力の順に小さ くなり自由地盤応答の場合と異なる.この現象は Fig.5 で示したメカニズムにより水平方向加速度の応答特性と 矛盾なく説明できる.すなわち， $50 \mathrm{gal} ， 100 \mathrm{gal}$ 入力
Table 2 Comparison of Maximum Response Ratio and Resonance Frequency between Free Ground Model and Soil Structure Model

\begin{tabular}{|c|c|c|c|c|}
\hline \multirow{2}{*}{$\begin{array}{r}\text { Input } \\
\text { Acc. }\end{array}$} & \multicolumn{2}{|c|}{ Horizontal } & \multicolumn{2}{|c|}{ Vertical } \\
\hline & Case 1 & Case 2 & Case 1 & Case 2 \\
\hline $50 \mathrm{gal}$ & $4.8(38)$ & $5.8(42)$ & $4.5(36)$ & 2. $2(41)$ \\
\hline $100 \mathrm{gal}$ & 3. $6(32)$ & 4. $0(40)$ & 3. $9(35)$ & 3. 5(36) \\
\hline 200 gal & $2.5(26)$ & $2.7(28)$ & 2. $9(34)$ & 2. $9(34)$ \\
\hline
\end{tabular}

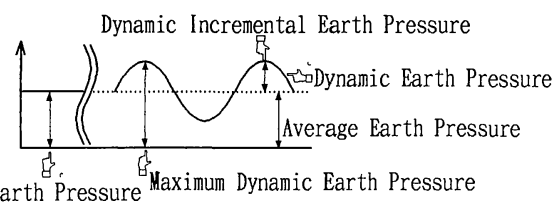

Static Earth Pressure Maximum Dynamic Earth Pressure

Fig.10 Definition of Various Kinds of Earth Pressures

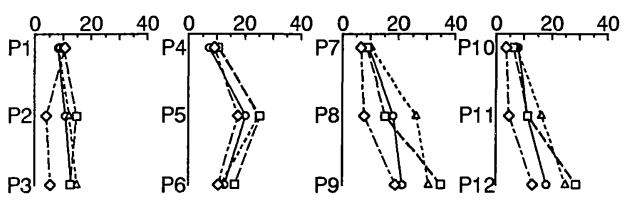

(a) $t=1.5 \mathrm{~cm}$ Pit Model

Unit;gf $/ \mathrm{cm}^{2}$ (98 Pa)

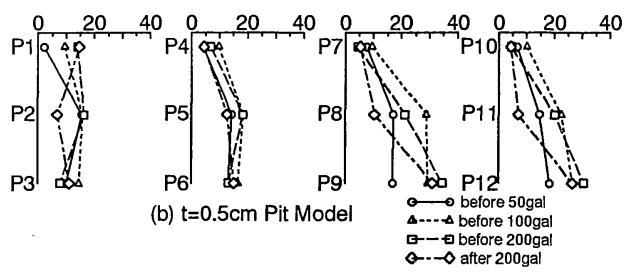

Fig.11 Distribution of Measured Static Earth Pressure

時には構造物の影響で地盤のせん断ひずみが小さく，そ れに伴う体積変化も減少するので上下振動が小さくなっ たと考えられる.

$200 \mathrm{gal}$ 入力時には地盤のせん断ひずみに対する構造 物の影響は小さく, それゆえ共振曲線は水平, 上下とも 自由地盤のものによく似ているのであろう．上下振動は 水平振動よりも構造物の影響を強く受けるようである.

c）動土圧と地盤振動特性の関係

本論文ではFig.10に示すように，振動時の土圧を動 土圧 ( $\mathrm{Pd})$, 動土圧の最大值を最大動土圧 ( $\mathrm{Pmd}$ ), 最 大値と最小值の平均を平均土圧 $(\mathrm{Pav})$, 最大動土压之 平均土圧の差を動的増分土圧 (Pdi), 振動台が静止状 態の土圧を静止土圧 (Pst) と称す。ここで動土圧の最 大值と最小值は定常状態の 10 波形の平均値とした.

静止土圧分布を, 縦軸に Fig.1 に示す土圧計の位置を 取って表すと，Fig.11に示すように各実験の前後で値 が変化する.これは後述するように振動実験中に平均土 圧が変化するためである. 振動台を停止したときの静止 土圧は実験終了直前の平均土圧に等しく，これは実験前 

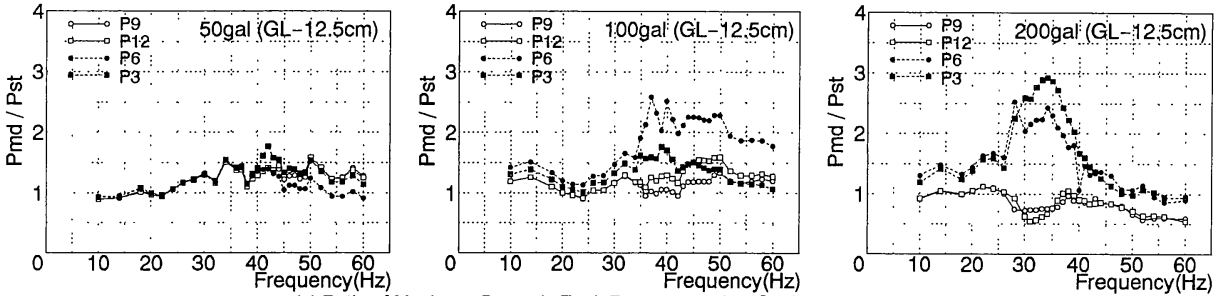

(a) Ratio of Maximum Dynamic Earth Pressure against Static Earth Pressure
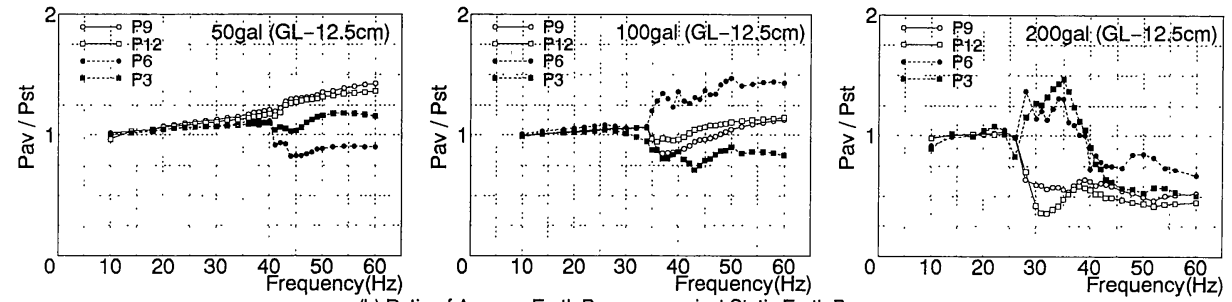

(b) Ratio of Average Earth Pressure against Static Earth Pressure
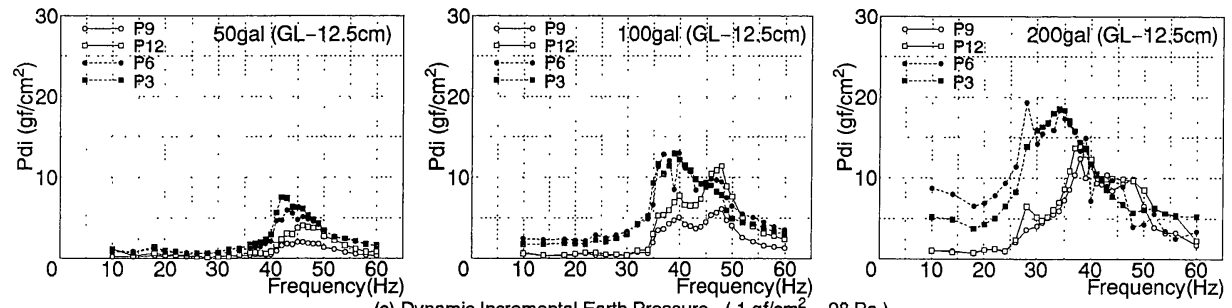

(c) Dynamic Incremental Earth Pressure (1 gf/ $\mathrm{cm}^{2}=98 \mathrm{~Pa}$ )

Fig.12 Relations between Three Types of Earth Pressures and Frequency

の値とは異なるのである.

Fig.12 は板厚 $1.5 \mathrm{~cm}$ 模型の場合の最大動土圧，平均 土圧，動的増分土压と振動数の関係を示した図である. 最大動土圧と平均土圧は各実験直前の静止土圧で除し無 次元化してある. Fig.11に示すように同一の深度であっ ても静止土圧が異なるので, Pstに対する変化量で表し た方が現象は理解し易いと考えた。

まず最大動土圧を見ると，振動方向に垂直な外壁面の 土圧 P 6, P 3 は入力加速度を増すと大きくなり，また 地盤の共振に関わる振動数依存性があるようである。平 行な外壁面に作用する土圧 P 9, P 12 の変化は入力加 速度と関係なく，振動数依存性も曖昧である.

次に平均土压と動的増分土圧に注目してみると，入力 $50 \mathrm{gal}$ の実験では $40 \mathrm{~Hz}, 100 \mathrm{gal}$ では $35 \mathrm{~Hz}, 200 \mathrm{gal}$ では $25 \mathrm{~Hz}$ を境に平均土圧は静止土圧からズレ, 動的増 分土圧は急に増加している様子が図より読み取れる. ま た，この振動数までは振動方向と平行な壁面の土圧計 P 9 と P 12 の動的増分土圧はかなり小さい。これらの 振動数は上下動の発生する振動数と一致している

(Fig.9).つまり，上下動の発生と共に平均土圧は静 止土圧からズレ，動的増分土圧は増大し振動方向と平行 な壁面にも動土圧が作用することを意味している．この 実験結果はFig.8 を参考にすると定性的に説明できる. 図中の a が実験直前の応力位置, すなわち静止土圧の状
態に対応し，上記の振動数までは $\mathrm{a}-\mathrm{b}$ 間で応力が変化 しているのである.この状態では上下動は発生せずまた $I_{1}$ の変化はないから平均土圧は実験前の静止土圧に等 しい．応力が降伏曲面に達すると上下動が生ずるととも に振動の中心位置は $\mathrm{a}$ からズレるため平均土圧は静止土 圧から離れていく.また, 上下動による動土圧が発生し, それは構造物全側面の動的増分土圧を増加させる．この 動的増分土圧は入力加速度の増加にともない大きくな り，振動数依存性も明確である.また，後述するように 振動方向と平行な外壁面にも動的な曲げひずみが生じて いることから，構造物の設計の際には重要である.

d）構造物の剛性と動土圧の関係

Fig.13 は最大動土圧の分布図である. 入力加速度を 増加させると板厚 $1.5 \mathrm{~cm}$ モデルの最大動土圧は大きく なる傾向にあるが，板厚 $0.5 \mathrm{~cm}$ モデルでは分布に大き な変化がないようである.しかし，Fig.14から，動的 増分土圧は板厚に関係なく入力加速度の増加に伴い大き くなることがわかる．この両土圧の傾向の差は前項で述 ベた平均土圧の変化に起因する. 動的増分土圧に注目し てみると, 振動方向と平行な壁面の土圧は構造物の風性 にあまり関係しないようである。垂直な壁面では構造物 の剛性が大きいと土圧は大きくなる．この壁面の動土圧 は水平動と上下動による動土圧の足し合わせであり，水 平動による動土圧が構造物の剛性の影響を受けるからで 


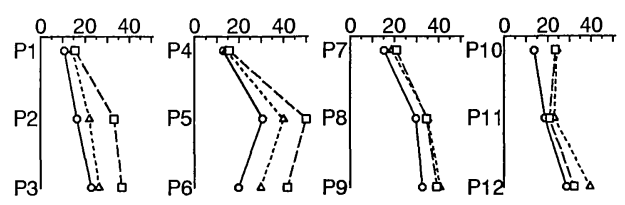

(a) $\mathrm{t}=1.5 \mathrm{~cm}$ Pit Model

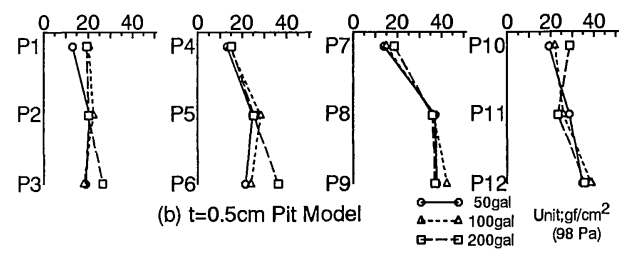

Fig.13 Distribution of Measured Maximum Dynamic Earth Pressure

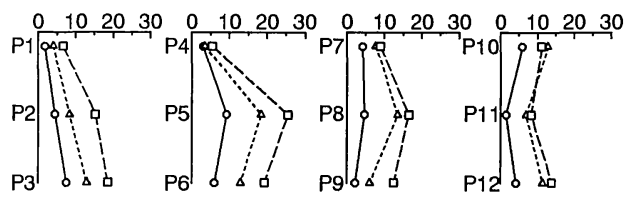

(a) $\mathrm{t}=1.5 \mathrm{~cm}$ Pit Model

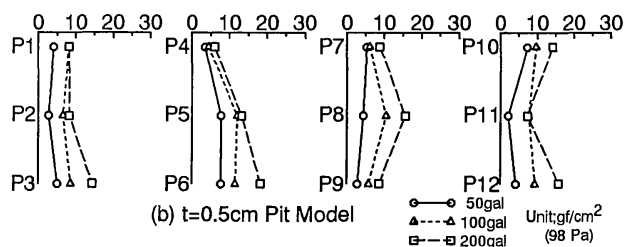

Fig.14 Distribution of Measured Dynamic Incremental Earth Pressure

ある. 構造物の剛性が大きいと地盤のせん断変形と構造 物の曲げ変形との相対変位が大きくなり, 相対変位に基 づく動土圧は増大する11!

e）動土圧の時刻歴波形の特徵

Fig.15 は板厚 $1.5 \mathrm{~cm}$ 模型の場合の動土圧の測定結果 の一例で, 縦軸は動土圧 Pd $200 \mathrm{gal}$ の実験直前の静 止土圧Pstで除し無次元化してある. 地震力に垂直な 壁面のP 1, P 2 と P 3 の波形の位相は逆転しており, 慣用法で用いられる静水圧分布形とは異なる。また， $P$ 3 では Pd/Pstが周期的に零の值を示している。これは 剥離を意味し, 本実験の場合, この例のように浅部より 深部の剝離が顕著であった. 地震力と平行な P $10, \mathrm{P} 11$, P 12 はほぼ同位相で振動しているが垂直な壁面の動土 圧の 2 倍の振動数を示し, 上下方向加速度の特徵と一致 している.剥離までには至らないが，Pd/Pstは周期的 に零に近い值を示し，この状態では側壁の直応力に比例 する摩擦抵抗力はほとんど期待できないことを示唆して いる.

f）構造物に生ずる曲げひずみの応答特性

Fig.16 は構造物の剛性が大きい場合には，振動方向 と平行な壁面の曲げひずみ S 2 が垂直な壁面のS 4 より も大きくなる場合があることを示している. 振動方向と

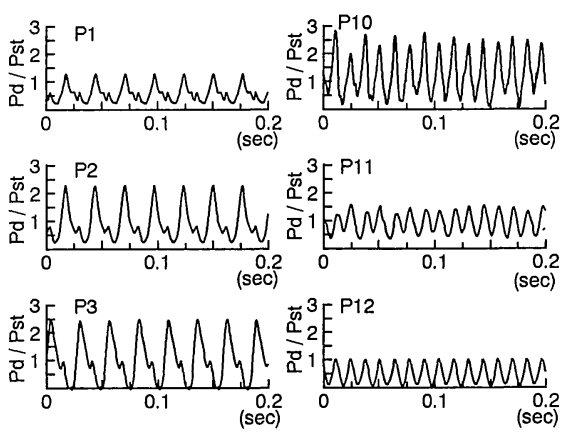

Fig.15 Measured Dynamic Earth Pressures (200 gal, 37Hz)
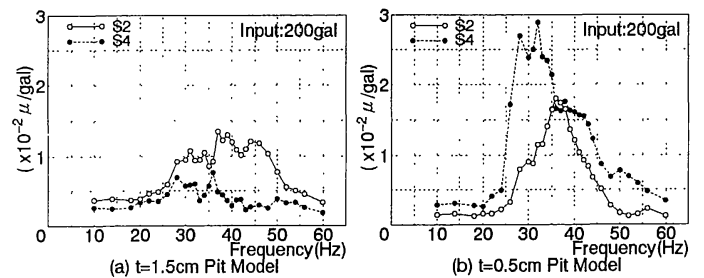

Fig.16 Relations between Measured Bending Strain of Wall and Frequency

垂直な外壁面のS 4 の曲げひずみの最大値は $t=1.5 \mathrm{~cm}$ 模型で $0.75 \times 10^{-2} \mu / \mathrm{gal}, t=0.5 \mathrm{~cm}$ 模型で $2.89 \times 10^{-2}$ $\mu / \mathrm{gal}$ でありその差は大きい. この面には上下振動と水 平振動による動土圧が作用する。上下振動による動土圧 は構造物全側面に同位相で作用するため構造物を一方向 に変形させることはないが, 水平振動による動土圧は振 動方向に垂直な両外壁面で片押し片引き状態になるの で，構造物をこの方向に曲げ変形させる．構造物の岡性 が小さいと構造物が地盤の動きに追従するため大きな曲 げ変形を生ずる.これは $t=0.5 \mathrm{~cm}$ 模型の動的増分土圧 が $t=1.5 \mathrm{~cm}$ 模型より小さいことからも裏付けされる. $t=0.5 \mathrm{~cm}$ 模型では構造物が地盤の動きに追従するため 地盤と構造物の相対変位が小さく動的増分土圧も小さく なる。

振動方向之平行な外壁面のS 2 の曲げひずみの最大值 は $t=1.5 \mathrm{~cm}$ 模型で $1.35 \times 10^{-2} \mu / \mathrm{gal}, t=0.5 \mathrm{~cm}$ 模型 で $1.79 \times 10^{-2} \mu / \mathrm{gal}$ であり大差はない.この面には上 下振動による動土圧のみが作用する.上述したように上 下振動による動土圧は構造物全側面に同位相で作用する ため構造物を一方向に変形させることはない, また, 縦 断方向には隔壁があり両模型とも十分に剛性が大きいこ とから剛性の違いが曲げひずみに与える影響は少ない。

\section{4. 結 論}

模型振動実験とFEM による自由地盤の弾塑性時刻 歴応答解析を行った結果以下の知見が得られた。

（1）地盤を水平方向に加振すると, ある振動数加ら突 然上下動が発生する.この上下動は水平動の 2 倍の振動 
数を持ち，その応答倍率は水平動と同等またはそれ以上 の值を示す.

（2）上記現象は地盤のダイレタンシー特性によって定 性的に説明できる.すなわち，せん断ひずみが大きくな ると体積変化を生ずるようになり，水平動とともに上下 動が発生するのである.

（3）さらに，この現象はFEMによる弾塑性時刻歴 応答解析でシミュレーションが可能である。解析結果か ら, 深部で応力が降伏曲面に達して塑性体積ひずみによ る上下動が発生すること，この上下動は上方に伝播され ることなどが明らかになった．これは岩盤上に表層地盤 がある場合，一般にその境界面付近のせん断ひずみが最 も大きくなるから，そこで上下動が発生し地表面まで伝 播することを示唆している.

（4）自由地盤模型と連成系模型の地盤の共振曲線を比 較すると，水平動より上下動の方が差異が大きく，地盤 と構造物の動的相互作用は上下動の方に大きな影響を与 えるという結果になった，応答倍率については，水平動 では連成系模型が自由地盤模型より大きいが，上下動で は自由地盤模型より大きくなることはなかった．構造物 の存在により地盤のせん断ひずみが小さくなる場合には この傾向は一般的に成立する.

（5）地中構造物の全外壁面には励起された上下動によ る動土圧が作用する．地震力に垂直な壁面にはさらに水 平動による動土圧も作用する．構造物の剛性の大小は, 水平動による動土圧には影響するが，上下動による動土 圧には影響が少ない。

（6）動土圧は平均土圧，動的増分土圧に分解すると地 盤振動との関係が明確になる。上下動の発生と同時に平 均土圧は静止土圧からズレ，動的増分土圧は増大した。 平均土圧が静止土压からズレることは，静止土压と動的 増分土王の足し合わせを地震時土圧とする従来の考え方 に制限を与えるものである。この方法は上下動が発生す るまで，すなわちせん断ひずみが小さい領域でのみ成立 する.
（７）構造物の剛性が大きい場合には，振動方向と平行 な壁面の曲げひずみが垂直な壁面よりも大きくなる場合 がある。

最後に，本研究の実験とデー夕整理に関して埼玉大学 卒論生八木橋功君 (現地域振興整備公団) の協力を得た。 ここに記して感謝の意を表したい。

参 考 文 献

1）石原研而：土質動力学の基礎，鹿島出版会，1978.

2）三浦賢治：長方形に近い断面を持つ地中基礎構造物の振 動特性について（その1）, 日本建築学会論文報告集，第 232 号, 1975 年 6 月.

3）土岐憲三・三浦房紀・大竹敏雄：3 次元ジョイント要素 に上る地盤一構造物系の非線形震動解析, 土木学会論文 報告集，第 322 号，1982 年 6 月.

4）石原哲哉・三浦房紀：3 次元構造物一地盤系の非線形地 震応答解析, 土木学会論文集, No. 465/I-23, pp. 145 - 154, 1993. 4.

5）香川崇章：土構造物の模型振動実験における相似則，土 木学会論文報告集, 第 275 号, 1978 年 7 月.

6）国生剛治・岩楯敞広：軟弱地盤の非線形振震動特性につ いての模型振動実験と解析，土木学会論文報告集，第 285 号, 1979 年 5 月.

7）井合進：1G 場での地盤・構造物系の模型振動実験の相似 則について, 第 19 回地震工学研究発表会, pp. 341 344, 1987.

8）渡辺啓行・末広俊夫：数值実験による地中ダクトの動的 水平直土压の評価, 土木学会論文集, No.432/I-16, pp. $165 \sim 174$, 1991. 7 .

9) W.F.Chen, G.Y.Baladi : SOIL PLASTICITY, Elsevier, 1985.

10）熟津久一郎・宮本博・山田嘉昭・山本善之・川井忠彦： 有限要素法ハンドブック I 基礎編, 培風館, 1988年4月.

11）当麻純一・国生剛治・岩楯敞広：非岩着地中構造物の耐 震設計に関する研究 (その 1 ) 模型振動実験による地盤・ ダクト系の動的応答の解明, 電力中央研究所研究報告, No. 383023,1984 年 2 月.

(1993.7.19 受付)

\title{
AN EXPERIMENTAL STUDY ON ELASTO-PLASTIC DYNAMIC INTERACTION OF 3-D UNDERGROUND STRUCTURE AND SOIL
}

Yoshitaka OHSHIMA and Hiroyuki WATANABE

\begin{abstract}
A model ground of air dried sand compacted in a shear testing apparatus and two composite models each of which had the model pit of different rigidity buried in same model ground as above one were excited horizontally with sinusoidal motions on a shaking table. From measured acceleration and dynamic earth pressure it has been found that the vertical vibration is produced in the ground due to the dilatancy or volume change of soil and yet it produces the dynamic earth pressure acting on all outside walls of the model pit.The vertical vibration is more strongly influenced on than the horizontal one by the dynamic soil-structure interaction. In addition, we show that the vertical vibration produced by horizontal exciting is able to be predicted by finite element procedure with elasto-plastic dynamic response analysis.
\end{abstract}

